\title{
Audit Committee Diversity toward Voluntary Disclosure Reporting With Existence of Regulatory Regime as Moderation Variable
}

\author{
Ali Shariff Kabara, Dewi Fariha Abdullah, Aniza Bint Othman
}

\begin{abstract}
The audit committee is a fundamental and prerequisite tool for fulfilling board's monitoring role of ensuring transparency, financial and managerial efficiency. Therefore, it has been applied to address perceived governance failure. This paper aims to critically review the previous literature on the relationship between audit committee diversity as a major corporate governance mechanism and corporate voluntary disclosure reporting (CVDR) with a change in the regulatory regime as moderation variable. This review specifically evaluates theoretical and empirical literature related to audit committee diversity like independence, financial expertise, accounting expertise; and CVDR in order to highlight some important areas of gaps for future research in this field. It also, emphases the need for a more qualitative method for better understanding of the relationship. This paper proposes that examining the moderating influence of the change of the regulatory regime with regard to CVDR would provide more insight into the link between audit committee diversity and CVDR. The policy implication of the study is also discussed. Lastly, the paper stresses the importance of studies linking audit committee diversity and CVDR, which are quite scanty in the existing literature.
\end{abstract}

Index Terms: Corporate governance; Audit committee diversity; Voluntary disclosure; Regulatory regime.

\section{INTRODUCTION}

The existence of corporate financial scandals in the gigantic companies like Enron in 2001, WorldCom, 2002; Global Crossing, 2002; Lenman Brothers in 2008, Saytam in 2009, Banco Espirito Santo (BES) in 2014 and Turing Pharmaceutical in 2015, have recently attracted greater concerns globally. Consequently, the inadequate disclosures by firms due to ineffectiveness of corporate governance attributes like audit committee diversity among which independence, financial expertise, accounting expertise is a major determinant, have been accepted as the major reason behind most of the corporate financial failures in the world world (Cadbury-Report, 1992; Ho and Wong, 2001; Klein, 2002; Catalyst, 2005; Borgia, 2005; Gulzar and Zongjun, 2011; Hili and Affes, 2012; Samaha, Khlif and Hussainey,

Revised Manuscript Received on 14 September, 2019.

Ali Shariff Kabara, Department of Accounting and Finance, Faculty of Management,Universiti Teknologi Malaysia, Johor, Malaysia, alishariff080@gmail.com

Dewi Fariha Abdullah, Department of Accounting and Finance, Faculty of Management, Universiti Teknologi Malaysia, Johor, Malaysia

Aniza Bint Othman, Department of Accounting and Finance, Faculty of Management, Universiti Teknologi Malaysia, Johor, Malaysia
2015; Wagana and Nzulwa, 2016; Hassan, et al., 2017).

According to Ferrari et al. (2016) and Fidanoski, Simeonovski and Mateska (2014) Asian financial crisis problem could have been prevented if the board and audit committee have been diversified. Many studies suggest that corporate board and audit committee diversity has become a contemporary topic especially because of its impacts on firms' performance (Katmon, et al., 2017). The topic of corporate governance can be traced back to several decades (Berle and Means, 1932) but as a subject of academic research it has grown enormously over the last two decades to the point that scholars have recently taken stock of the state of the field (e.g. (Durisin \& Puzone, 2009; Boyd, Haynes, \& Zona, 2011; Daily, Dalton, \& Cannella, 2003; McMulty, 2013)

This review specifically intends to evaluate theoretical and empirical literature related to audit committee diversity and voluntary disclosure reporting, hereinafter, referred to as ACD and CVDR respectively; with a view of establishing areas of gaps for future research both theoretical and methodological. Furthermore, it highlights the importance of more qualitative methods and longitudinal studies for an in-depth understanding of the relationship between the two variables under review. The next section will discuss conceptual framework and literature review, followed by a theoretical review. Next section will discuss empirical review followed by critical review of existing literature. Next is conclusion and recommendation for future research, then lastly the implication of the research follows.

\section{CONCEPTUAL FRAMEWORK AND LITERATURE REVIEW}

The concept of voluntary disclosure: Voluntary disclosure is defined by (Meek, Roberts and Gray (1995 p. 555) as "free choices on the part of company management to provide accounting and other information deemed relevant to the decision needs of users of their annual reports." Moreover, in their part Hassan and Marston (2010, p.7) voluntary disclosure may include disclosure "recommended by an authorization code or body". Meanwhile, codes of CG or good practice are also voluntary in nature, as obtainable in Nigeria and many parts of the globe both developed and developing economies like UK and China.

According to Gelb (2000, p. 169) investors lack first-hand access to information, may lead to increased demands 
for organizational information that can be used to monitor management. In this respect, (McKinnon \& Dalimunthe, 2009 , p. 37) suggest that voluntary disclosure may be helpful in reducing conflicts between managers and shareholders that arise when a firm's shares are widely held. Furthermore, Creswell and Taylor (1992, p. 299) argue that increases in the separation of ownership and control are likely to be accompanied by additional disclosures of information to third parties. Below is the frame work that shows the direct and indirect relationship among the variables.

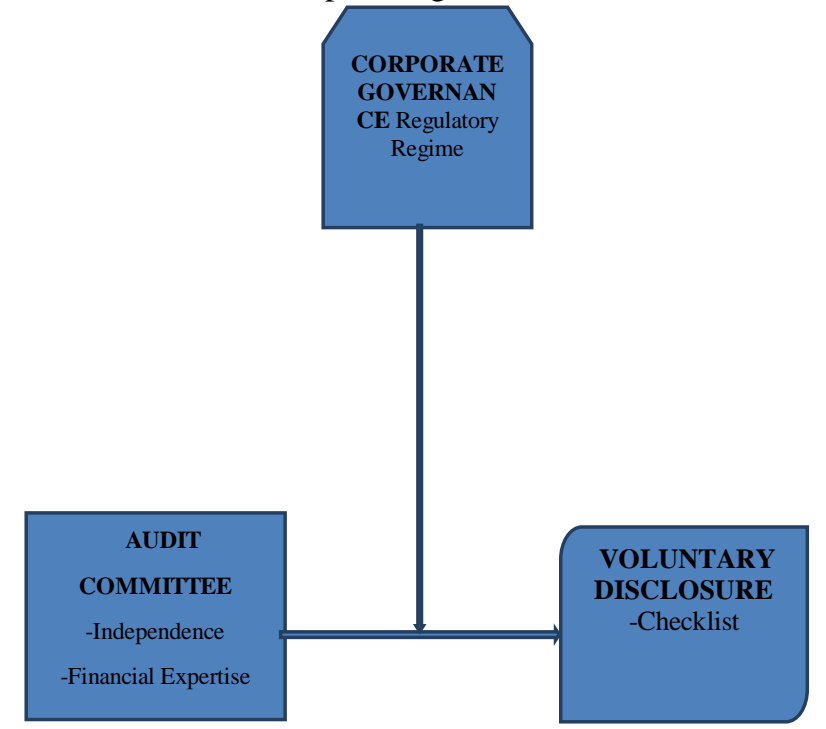

Fig 2.1: The Research Framework - Model adapted from Hayes (2013)

\section{A. Conceptual Definitions: Corporate Governance and Audit Committee Diversity}

Denis and McConnell (2002, p. 1-2) defined CG as: “...the set of mechanisms - both institutional and market-based that induce the self-interested controllers of a company... to make decisions that maximize the value of the company to its owners..."Conversely, Solomon (2013) also, defined CG as: "the system of checks and balances, both internal and external to companies, which ensure that companies discharge their accountability to all their stakeholders and act in a socially responsible way in all areas of the of their business activity (p.14)."

The concept of AC have been define by many scholars from different perspective, among which Uzun, Szewczyk and Varma (2004, p.6) defined audit committees as being "responsible for overseeing the financial reporting process and ensuring the objectivity of the external audit" However, in addition to monitoring role of financial reporting process as indicated in the above definition, independence of the audit committee members can also be significantly contribute to the committee's effectiveness (Xie, Davidson, and Dadalt, 2003), as it enables the committee to carry out its responsibilities objectively (Abbott, Parker and Peters, 2004).Therefore, in the context of this study audit committee is said to be diversified when it contains an independent director and members with finance or accounting background.

\section{THEORETICAL REVIEW}

\section{A. Agency theory and Voluntary Disclosure}

Researchers all over the world considered agency theory developed by Jensen \& Meckling (1976) as the most relevant in explaining corporate governance and voluntary disclosure (see: Ho and Wong, 2001; Gul and Leung, 2004; Arcay and Vazquez, 2005; Sukthomya, 2011; Chithambo, 2013; Alotaibi, 2014; Samaha et al., 2015). According to Lambert (2001 p.4), the rationale behind choosing of agency theory by accounting scholars is that: "It allows us to explicitly incorporate conflicts of interest, incentives problem and mechanism for controlling incentives problem into our models"

In this type of research, voluntary disclosure presents an excellent opportunity to apply agency theory, in the sense that managers (the agents) who have better access to a firm's private information can make a credible and reliable communication to the market to optimize the value of the firm. These disclosures include investment opportunities and financing policies of the firm. Conversely, managers may, in pursuit of their personal goals, fail to make proper disclosure or non-disclosure of important information to the market. Such practices may be detrimental to the interests of shareholders (the principals). This may result in a higher cost of capital and, consequently, shareholders may suffer a lower value for their investments (Barako, Hancock, \& Izan, 2006b). The Agency theory is relevant to this field of study because the sampled companies taken are those mostly listed on the Stock Exchange. The management of these companies is separated from the owners (shareholders) and is required by the respective legal and regulatory authorities to render the account of stewardship to the shareholders at the annual general meetings.

\section{B. The Stakeholder Theory, Board Diversity and Audit Committee}

Freeman (1984) defines stakeholders as a "wide range of individuals and groups who can affect, or are affected by, corporate activities". However, stakeholders theory incorporates corporate accountability to a broad range of stakeholders not necessarily shareholders per se (Freeman, Wicks, and Parmar, 2004). These groups include women and other minorities, customers, governmental bodies etc., (Brunk, 2010; Garba \& Abubakar (2014). According Solomon, (2010, p.15) the theoretical basis of stakeholder theory can be observed as follows: "companies are so large, and their impact on society so pervasive, that they should discharge accountability to many more sectors of society than solely their shareholders .... Not only are stakeholders affected by companies, but they, in turn, affect companies in some way".

Unlike agency theory, stakeholder theory assumes that managers are accountable to all stakeholders (Chen and Roberts, 2010). Nevertheless, stakeholders approach to corporate governance implies a shift in the traditional role of the board of directors, as a defender of shareholders

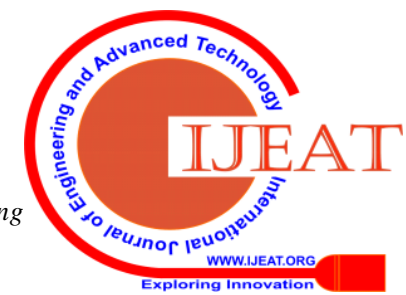


interest alone, to a defender of all stakeholders' interest. Therefore, one can infer from the stakeholder theory that, it is not the interest of the shareholders alone that should be protected, but also that of women and other minority groups (racial, cultural, and ethnic minorities). In this regard, however, a board is expected to use more diversified mechanisms to control and motivate the executives (Pige, 2002). The use of a diversified mechanism to control the excesses of the CEO may include gender diversity and diversity in other related variables like audit committee (e.g. independence, educational level and background and experience of the members, etc).

\section{Signaling Theory and Voluntary Disclosure}

Signaling theory has been employed as a possible explanation of voluntary disclosure practices, of which environmental disclosure is a significant category (AbuRaya, 2012). Signaling is a reaction to information asymmetry where managers have more information than stakeholders have. Signaling theory shows how information asymmetry can be reduced when the party with more information signals it to others (Morris, 1987).

The theory has been used in many studies to explain disclosure decisions by managers. However, some criticism has been made against some of its assumption like the assumption of signaling theory that managers are acting in their own interest and assumption of equal distribution of power. Some scholars argue that it is not individuals who exercise power but institutions (Gray, Owen, and Adams, 1996). Notwithstanding, voluntary disclosure is one of the signaling means, where companies would disclose more information than the mandatory ones required by laws and regulations in order to signal that they are better (Campbell, Shrives, and Saager, 2001; Shehata, 2014)

\section{Empirical Review}

The audit committee is said to be independent when the composition contained independent non-executive directors (INED) as the majority. The extant literature provides empirical evidence supporting the role of non-executive directors in promoting higher transparency and better disclosure policies (Arcay \& Vazquez, 2005). Prior researchers on disclosure have empirically linked board independence and voluntary disclosure. Whilst other studies found negative or no relationship among the two variables (Alshfire et al., 2016; Wu, Patel, and Perera, 2015; Chithambo, 2013; Li, Mangena, and Pike, 2012; Gulzar and Zongjun, 2011; Abdullah, 2006; Barako, Hancock and Izan, 2006a; Abbott et al., 2004) many of them reported positive and significant relationship (see, Rouf, 2016; Bin-Ghanem and Akmalia, 2016; Samaha, Khlif and Hussainey., 2015; Liao, Luo, \& Tang, 2015; Madi, Ishak and Manaf., 2014; AbuRaya, 2012; Akhtaruddin and Haron, 2010; Cheng and Courtenay, 2006).

Akhtaruddin and Haron (2010) examine the linkages between board ownership, audit committees' (ACs) effectiveness in terms of the proportion of independent non-executive directors (INED) and expert members on the $\mathrm{AC}$ and corporate voluntary disclosures. Using a sample of
124 public listed companies in Malaysia. The empirical results indicate the proportion of INED on the AC indicating that INED moderate board ownership/corporate voluntary disclosure relationship. What can be deduce from the above findings is that, an increase in the number of independent directors on the AC lead to an increase in disclosure levels at the same time reduce information asymmetry between firm management and investors. Moreover, Li, Mangena, and Pike (2012) argue that ACs with financial expertise are likely to be in a better position to understand the capital market implications of providing quality Internal Control (IC) disclosures. Such understanding of the AC should lead to improvement in IC disclosure in order to communicate information on firms' value-creating processes.

Moreover, the result of prior empirical studies, like, Dewayanto (2017) indicated that audit committee members having more knowledge of financial reporting finance have a greater possibility of showing and detecting material misstatements. In their part, Bin-Ghanem and Akmalia (2016) examine the effect of the board of directors and audit committee effectiveness on the level of internet financial reporting (IFR) disclosure practices. Using multivariate analyses the results shows that there is a positive significant association between audit committee effectiveness (measured by members' financial expertise) and the Internet Financial Reporting Disclosure (IFR), i.e. the greater the effectiveness of the audit committee members in terms of financial knowledge, the higher the level of the IFR disclosure. In addition, Abernathy et al. (2014) investigate the association between audit committee (AC) members' financial expertise and financial reporting timeliness. The result indicated that $\mathrm{AC}$ accounting financial expertise is associated with timelier accounting information. Further analysis also, reveals that accounting expertise gained from public accounting experience is associated with timelier financial reporting. Al-Shaer et al. (2017) in his study Audit committees and financial reporting quality: evidence from UK environmental accounting disclosures. Where audit committee quality is measured in a composite fashion. Smith compliance is indicated where all committee members are independent non-executive directors, there are three or more meetings per year, there is at least one committee member with financial expertise and the committee size is greater than three. Using multiple regressions analysis the result indicated that audit committee financial expertise significantly increases the quality of disclosure.

Song and Windram (2004) examine the effectiveness of UK audit committees in their primary responsibility of overseeing financial reporting in the period from 1991 to 2000. A logit regression approach results suggest that director financial literacy and an "active" audit committee may contribute to audit committee effectiveness. In conformity with the above finding, Cohen, et al. (2014) suggest that industry expertise, when combined with accounting expertise, can improve the effectiveness of the audit committee in monitoring the financial reporting process. DeFond, Hann, and $\mathrm{Hu}$ (2005) 
also conducted a study on a sample of firms with financial accounting expertise and non-financial accounting skills in their audit committee and find a positive stock market reaction to those shown.

All the empirical evidence presented above has consistently shown that audit committee financial expertise is positively related to voluntary disclosure. Whereas, other scholars (see, Madi, Ishak, and Manaf, 2014; Li, Mangena, and Pike, 2012; Abbott et al., 2004) argued that based on their empirical analysis, there is a negative or no relationship between the two variables. For example, Madi, Ishak, and Manaf (2014) investigated the influence of audit committee characteristics on corporate voluntary disclosure of 146 Malaysian listed firms for the year 2009. Based on content analysis of disclosure, the empirical results of multiple regressions reveal that financial expertise of audit committee members is not significantly associated with corporate voluntary disclosure. In the same vein, $\mathrm{Li}$ et al. (2012) using a data from 100 UK IC-intensive sector companies that were fully listed on the London Stock Exchange (LSE) as at 30 December 2005, investigates the relationship between audit committee characteristics and intellectual capital (IC) disclosure. The data analysis results indicated no significant relationship between IC disclosure and audit committee financial expertise.

Abbott et al. (2004) study address the impact of certain audit committee characteristics identified by the BlueRibbon Committee on Improving the Effectiveness of Corporate Audit Committees (BRC) on the likelihood of financial restatement. After examining 88 restatements of annual results (without allegations of fraud) in the period 1991-1999, the results document a significant negative association between an audit committee that includes at least one member with financial expertise and restatement. Considering the importance of having experts in the audit committee, many countries incorporate it in their code of corporate governance. For example, the Malaysian Code of Corporate Governance (MCCG, 2002) demanded that as in any composition of the audit committee at least one member must have professional qualifications in either accounting or financial expertise (Othman, et al. (2014). Similarly, SEC gives a definition of financial expertise, as an individual who has education and experience in accounting or auditing (e.g., auditor, CFO, financial controller or accounting officer). The fact that, many recent studies use SEC's definition to measure accounting expertise (e.g., Alshfire et al., 2016 and Abernathy et al., 2014) therefore, this study also adopts the same.

Othman et al. (2014) examine the influence of audit committee characteristics on voluntary ethics disclosures of the top 94 companies listed on Bursa Malaysia. The study employs content analysis of company's annual report and multiple linear regressions. The result of the study revealed no relationship between audit committee accounting expertise and the voluntary ethics disclosure. Another researcher from Asia, Dewayanto (2017) examine the effect of ownership structure and the audit committee on the internal control disclosure in different board system on one cluster of environment, i.e. French Civil Legal system, between Indonesia and the Philippines between 2009 and 2013 in Indonesia Stock Exchange (1,792 companies) and the Philippines (1,457 companies). The result of multiple regression revealed that the influence of the audit committee with accounting background on the disclosure of internal controls proves to be positive and significant. They are further, argue that the appointment of accounting experts in an audit committee is expected to improve corporate governance through better supervision.

Razek (2015) from Cairo, investigate the association between corporate social responsibility disclosure and corporate governance in Egyptian companies, using SPSS statistical analysis, the result indicated that skills and qualification of audit committee members are the most significant factor determinants of corporate social responsibility disclosure. A similar result on the same topic of social responsibility was found by an American researcher Harjoto et al. (2015) who examined the impact of board diversity on firms' corporate social responsibility (CSR) performance. Using seven different measures of board diversity across 1,489 U.S. firms from 1999 to 2011, the result confirmed that expertise diversity reduces CSR performance. In addition, Harris (2016) Using U.S. companies from 2003-2013, examines the influence of audit committee professional diversity (defined as the variation of group knowledge) on the committee's effectiveness. The results also indicated a positive association between the professional diversity of the audit committee and financial reporting oversight. In contrast, Cohen et al. (2014) found similar results that, audit committee members who are both accounting and industry experts perform better than those with only accounting expertise. Further argued that industry expertise, when combined with accounting expertise, can improve the effectiveness of the audit committee in monitoring the financial reporting process. More precisely, Abernathy et al. (2014b) found a similar positive association between audit committee (AC) members' financial expertise and financial reporting timeliness, from the result of multivariate regression analysis.

Conversely, a dissimilar result was found by Alshfire et al. (2016) who examined the effects of audit committee competence and moderating auditor quality on the timeliness of financial reporting in manufacturing companies in Indonesia. Using 92 samples listed firms in Indonesia Stock Exchange (IDX) for the period of 2010-2012. The empirical result showed that competence of the audit committee (measured by accounting or finance experience), is not proven to affect the timeliness of the financial reporting.

\section{E. The Effect of Regulatory Regime in the relation to AC and VD}

An effective audit committee has qualified members with the authority and resources to protect stakeholders' interests by ensuring reliable financial reporting, internal controls, and risk management through its diligent oversight efforts 
(Martinov-Bennie, Soh, \& Tweedie, 2015). On one hand, companies with ACs are more likely to have higher financial reporting quality McMullen, (1996). The quality of management disclosure can be improved through regulation, standard establishment, auditors, and other capital market intermediation (Healy \& Palepu, 2001). Moreover, Gillan (2006) opines that the legal and regulatory environment is integrally related to CG (see, Leuz, Triantis, \& Yue Wang, 2008; Daouk, Lee, \& Ng, 2006)

In light of the foregoing, this current review believed that change in regulatory regime can moderate the relationship between ACD (independent variables) and CVDR (the dependent variable) consistent with Inchausti, (1997). More precisely, Cheng \& Courtenay (2006 p. 30) found that: "the presence of an external corporate mechanism, the regulatory regime, enhances the strength of the association between the proportion of independent directors and the level of voluntary disclosure." Since empirical studies confirmed that changes in the regulatory regime only exert a significant influence between the AC, and CVDR not as a causal effect, hence it confirm that moderation analysis became most relevant for the study between ACD and CVDR. MacKinnon, Fairchild, and Fritz (2007) described the mediator as a variable that is in a causal sequence between two variables, whereas a moderator is not part of a causal sequence between the two variables.

Importantly, according to Martinov-Bennie et al. (2015) ACs have been used to address perceived governance failures from their inception Walker (2004) demonstrates that almost all the major international regulatory expansions of the role of ACs have followed prominent cases of fraud or corporate collapse, or other types of public governance failures. A well-known example is the Cadbury Committee in the UK in 1992, which followed public revelations of corporate fraud, misuse of power and stock manipulation (C. Boyd, 1996). The Cadbury Committee recommended that ACs become compulsory for all listed entities, on the basis that ACs enhance the capacity of non-executive directors to exercise independent oversight of financial statements (Walker, 2004).

Most recently, García-Sánchez, García-Meca, and Cuadrado-Ballesteros (2017) in their study on relationship between the presence of financial experts on audit committees and the levels of insolvency risk in the banking sector for the period 2004-2010. Their empirical results suggest that the presence of financial experts on audit committees is useful to reduce insolvency risk, supporting the monitoring advantage hypothesis of financial expertise. This relationship is stronger when banking sector regulation is weaker and also in banks with stronger policies against unethical practices.

\section{FINDINGS FROM THE CRITICAL REVIEW OF EXISTING LITERATURE}

Importantly, the above review revealed that in addition to independence, finance and accounting background diversity, other variables that had been frequently used in the previous studies are: AC size, AC meetings. It is observed that very few studies test the following AC variables on voluntary disclosure such as their professional expertise, industry's experience and the age influence of an $\mathrm{AC}$ member and their ethnic diversity. It is professed that the negative result frequently found between ACD and VDR could have been turning to positive if other important variables are used in the model, the future empirical researchers may find them beneficial.

Secondly, it was found that qualitative research on the topic under review have been very rare for the last three decades. For example, previous research confirmed that only single qualitative research was published before the ' 90 s, 13 in the ' 90 s and 58 between 2000-09, with little increase to 7 articles published between 2010 and 2011, after reviewing 78 qualitative research articles in peer review journal which was screened from 1040 articles on CG (McNulty, Zattoni, \& Douglas, 2013). This confirms that there are methodological drawbacks in previous research as also claimed by previous studies like Kamonjoh, 2014; Rao and Tilt, 2016; Wagana and Nzulwa, 2016).

Thirdly, our finding also shows that previous literature confirmed regulatory regime, enhances the strength of the association between the proportion of independent directors and the level of voluntary disclosure. Notwithstanding, very few studies attempt using it on corporate governance studies.

Lastly, most of the previous study used an agency, signaling and stakeholders theories in explaining $\mathrm{AC}$ diversity and corporate voluntary disclosure, for example, Mohd-Nasir and Abdulah, 2004; Hongxia and Ainian, 2008; Chau and Gray, 2010; Juhmani, 2013; Wang and Hussainey, 2013; Samaha et al., 2015). After conducting a critical literature review researchers like Kamonjoh (2014); Rao \& Tilt (2016); Wagana and Nzulwa (2016) argued that there are methodological drawbacks in previous research.

\section{CONCLUSION AND RECOMMENDATION FOR FUTURE RESEARCH}

This study reviewed theoretical and empirical literature related to ACD and CVDR, with the regulatory regime as moderation variable. The main aim is establishing areas of gaps for future research both theoretical and methodological. In addition, to highlights, the importance of more qualitative methods studies for an in-depth understanding of the relationship between the two variables.

Conclusively, the concept of CG (i.e. regulatory regime) was confirmed to be having an important effect of strengthening the level of relationship between the AC and the level of voluntary disclosure (Chau \& Gray, 2002 and Arcay, and Vazquez, 2005). As there is very limited research linking the regulations (as an external corporate governance mechanism) with ACD in relation to CVDR, hence future researchers have an important gap for empirical investigations.

Moreover, qualitative research on the topic under review was found to be very rare for the past three decades, even though it helps for an in-depth understanding of the quantitative results. Therefore, future 
research should consider using the qualitative method to overcome the shortcomings of using quantitative method alone.

Additionally, based on the findings of this study, future research should provide evidence from RBV theory view point in addition to the agency, signaling and stakeholder theories.

Lastly, the above findings also revealed that professional expertise, industry's experience and the age influence of an AC member and their ethnic diversity are contemporary variables that received limited attention by the previous research. Hence, future research has a very good avenue for further investigations.

\section{THE IMPLICATION OF THE RESEARCH}

\section{A. Theoretical/Knowledge Contribution}

This paper is positioned as a contribution to stand along with other recent reviews of the state of knowledge in corporate governance such as McNulty (2013) Developing corporate governance research through qualitative methods: A Review of previous studies; Yasin, Muhamad, \& Sulaiman (2014) Corporate Governance Research: A Review of Qualitative Literature; and Samaha et al., (2015) The impact of board and audit committee characteristics on voluntary disclosure: A meta-analysis. Other relevant contibutions includes:

1. Integrates the literature on AC diversity and CVDR.

2. Confirmed the positive, direct influence of AC's diversity roles on CVDR.

3. Established the moderating effects of regulatory regime on CVDR.

4. Confirmed AC diversity as a continuously evolving concept.

\section{B. Practical Implications: Practitioners/Policy}

Moreover, other practical contributions of this study includes among others:

1. It pinpoints and broaden the understanding of future public policy makers regarding which aspects of AC have the greatest impact on disclosure reporting.

2. Highlights the need for Government and regulatory agencies to improved efforts at sensitizing companies on the relevance of CVDR.

3. Reveals the important dimensions of voluntary disclosure perceived by listed companies, for instance, CSR and Environmental Disclosure.

4. Highlights the importance of audit committee diversity as a complementary strategy to influence CVDR.

5. Highlights the need and importance for companies in developing economy to understand the roles of AC diversity in influencing CVDR, which invariably increases the value of the firm.

\section{REFERENCES}

[1] Abbott, L. J., Parker, S., and Peters, G. F., \& Peters, G. F. (2004). Audit committee characteristics and restatements. Auditing: A Journal Of Practice and Theory, 23(1), 69-87. https://doi.org/10.2308/aud.2004.23.1.69

[2] Abdullah, S.-N. (2006). Board composition, audit committee and timeliness of corporate financial reports in Malaysia. Corporate Ownership \& Control, 4(2).

[3] Abernathy, J. L., Beyer, B., Masli, A., \& Stefaniak, C. (2014). The association between characteristics of audit committee accounting experts, audit committee chairs, and financial reporting timeliness. Advances in Accounting, 30(2), 283-297. https://doi.org/10.1016/j.adiac.2014.09.001

[4] AbuRaya, R. K. (2012). The Relationship Between Corporate Governance and Environmental Disclosure: UK Evidence. Durham University. Retrieved from http://etheses.dur.ac.uk

[5] Akhtaruddin, M., \& Haron, H. (2010). Board ownership, audit committees' effectiveness, and corporate voluntary disclosures. Asian Review of Accounting, 18(3), 245-259. https://doi.org/10.1108/13217341011089649

[6] Al-Shaer, H., Salama, A., \& Toms, S. (2017). Audit committees and financial reporting quality: evidence from UK environmental accounting disclosures. Journal of Applied Accounting Research, 18(1). https://doi.org/10.1108/IJBM-07-2013-0069

[7] Alotaibi, B. M. N. A. (2014). Corporate Governance and Voluntary Disclosure in Kuwait. University of Bedfordshire. Retrieved from http://web.b.ebscohost.com.idpproxy.reading.ac.uk/ehost/pdfviewer/pdf viewer?vid=3\&sid=82a176d9-4e3a-4016-a3b5-f633541bcbad\%40sess ionmgr 198\&hid $=128$

[8] Alshfire, F. M., Subekti, I., \& Widya, Y. (2016). The effect of audit committee characteristics on timeliness of financial reporting by Using auditor quality and the moderating variable (An Empirical Study From Indonesian Manufacturing Companies). The International Journal of Accounting and Business Society, 24(1), 1-34. Retrieved from http://ijabs.ub.ac.id/index.php/ijabs/article/view/296

[9] Arcay, B. R. M., \& Vazquez, M. F. M. (2005). Corporate characteristics, governance rules and the extent of voluntary disclosure in Spain. Advances in Accounting, 21(5), 299-331. https://doi.org/10.1016/S0882-6110(05)21013-1

[10] Barako, D. G., Hancock, P., \& Izan, H. Y. (2006a). Factors influencing voluntary corporate disclosure by Kenyan companies. Corporate Governance, $14(2), \quad 107-125$ https://doi.org/10.1111/j.1467-8683.2006.00491.x

[11] Barako, D. G., Hancock, P., \& Izan, H. Y. (2006b). Relationship between corporate governance attributes and volutanry disclosures in annual reports: The Kenyan experience. Journal of Financial Reporting, Regulation and Governance, 5(1), 1-25.

[12] Bin-Ghanem, H., \& Akmalia, A. M. (2016). The effect of board of directors and audit committee effectiveness on internet financial reporting: Evidence from gulf co-operation. Journal of Accounting in Emerging Economies, 6(4), 429-448. https://doi.org/10.1108/JAEE-07-2014-0037

[13] Borgia, F. (2005). Corporate Governance and Transparency Role of Disclosure: How Prevent New Financial Scandals and Crimes? School of International Service. Washington D.C.

[14] Boyd, B. K., Haynes, K. T., \& Zona, F. (2011). Dimensions of CEOBoard relations. Journal of Management Studies, 48, 1892-1923.

[15] Boyd, C. (1996). Ethics and corporate governance: the issues raised by the Cadbury report in the United Kingdom. Journal of Business Ethics, 15(2), 167-182.

[16] Brunk, K. . (2010). Exploring origins of ethical company/brand perceptions-a consumer perspective of corporate ethics. Journal of Business Research, 63(3), 255-262.

[17] Cadbury-Report-Committee. (1992). The Financial Aspects of Corporate Governance. London: Gee and Co. Ltd.

[18] Campbell, D., Shrives, P., \& Saager, H. B. (2001). Voluntary disclosure of mission statements in corporate annual reports: signaling what and to whom? Business and Society Review, 106(1), 65-87. https://doi.org/http://dx.doi.org/10.1111/0045-3609.00102

[19] Catalyst. (2005). Census of Women Board Directors of the Fortune $500 . \quad$ Retrieved from http://www.catalyst.org/knowledge/2005-catalyst-census-women-boarddi

[20] Chau, G., \& Gray, S. J. (2010). Family ownership, board independence and voluntary disclosure: Evidence from Hong Kong. Journal of International Accounting, Auditing and Taxation, 19(2) 93-109. 
https://doi.org/10.1016/j.intaccaudtax.2010.07.002

[21] Chau, G. K., \& Gray, S. J. (2002). Ownership structure and corporate voluntary disclosure in Hong Kong and Singapore. The International Journal of Accounting, 37(2), 247-265.

[22] Chen, J., \& Roberts, R. (2010). Toward a more coherent understanding of the organization-society relationship: A theoretical consideration for social and environmental accounting research. Journal of Business Ethics, 97, 651-665.

[23] Cheng, E. C. M., \& Courtenay, S. M. (2006). Board composition , Accoun Ting, 41(3), 262-289. https://doi.org/10.1016/j.intacc.2006.07.001

[24] Chithambo, L. (2013). The Extent and Determinants of Greenhouse Gas Reporting in the United Kingdom. PhD Thesis. Bournemouth University.

[25] Cohen, R. J., Hoitash, U., Krishnamoorthy, G., \& Wright, M., A. (2014). The effect of audit committee industry expertise on monitoring the financial reporting process. Accounting Review, 89(1), 243-273. https://doi.org/10.2308/accr-50585

[26] Daily, C. M., Dalton, D. R., \& Cannella, A. A. (2003). Corporate governance: Decades of dialogue and data. Academy of Management Review, 28, 371-382.

[27] Daouk, H., Lee, C. M. C., \& Ng, D. (2006). Capital market governance: How do security laws affect market performance? Journal of Corporate Finance, $12(3)$, 560-593 https://doi.org/10.1016/j.jcorpfin.2005.03.003

[28] DeFond, M., Hann, R., \& Hu, X. (2005). Does the market value financial expertise on audit committees of boards of directors? Journal of Accounting Research, 43(2), 153-193.

[29] Denis, D. K., \& McConnell, J. J. (2002). International corporate governance. Journal of Finance and Quantitative Analysis, 38(1), 1-36. https://doi.org/doi.org/10.2307/4126762

[30] Dewayanto, T. (2017). Audit committee toward internal control disclosure with the existence of foreign directors as moderation variable. Review of Integrative Business and Economics Research, 6(3), 324-332.

[31] Durisin, B., \& Puzone, F. (2009). Maturation of corporate governance research,1993-2007: An assessment. Corporate Governance: An International Review, 17, 266-291.

[32] Ferrari, G., Ferraro, V., Profeta, P., \& Pronzato, C. (2016). Gender quotas: Challenging the boards, performance, and the stock market. CESifo Working Paper Series No. 6084., (10239). Retrieved from ssrn: https://ssrn.com/abstract $=2866376$

[33] Fidanoski, F., Simeonovski, K., \& Mateska, and V. (2014). The impact of board diversity on corporate performance: New evidence from Southeast Europe. Corporate Governance in the US and Global Settings, 26, 81-123. https://doi.org/10.1108/MBE-09-2016-0047

[34] Freeman, R. E. (1984). Strategic Management: A Stakeholder Approach. Boston, MA: Pitman. and the corporate objective revisited. Organization Science, 15(3), 364-369.

[36] Garba, T., \& Abubakar, B. A. (2014). Corporate board diversity and financial performance of insurance companies in Nigeria: an application of panel data approach. Asian Economic and Financial Review, 4(2), 257-277. https://doi.org/http://aessweb.com/journal-detail.php?id=5002

37] García-Sánchez, I. M., García-Meca, E., \& Cuadrado-Ballesteros, B. (2017). Do financial experts on audit committees matter for bank insolvency risk-taking? The monitoring role of bank regulation and ethical policy. Journal of Business Research, 76, 52-66. https://doi.org/10.1016/j.jbusres.2017.03.004

[38] Gillan, S. L. (2006). Recent developments in corporate governance: An overview. Journal of Corporate Finance, 12(3), 381-402. https://doi.org/10.1016/j.jcorpfin.2005.11.002

[39] Gray, R., Owen, D., \& Adams, C. (1996). Accounting and Accountability: Changes and Challenges in Corporate Social and Environmental Reporting. London: Prentice-Hall.

[40] Gul, F.A. and Leung, S. (2004). Board leadership, outside directors expertise and voluntary corporate disclosures. Journal of Accounting and Public Policy, 23(5), 351-379.

[41] Gulzar, M. A., \& Zongjun, W. (2011). Corporate governance characteristics and earnings management: Empirical evidence from Chinese listed firms. International Journal of Accounting and Financial Reporting, 1(1), 133. https://doi.org/10.5296/ijafr.v1i1.854

[42] Harjoto, M., Laksmana, I., \& Lee, R. (2015). Board diversity and 641-660. https://doi.org/10.1007/s10551-014-2343-0 regulatory regime and voluntary disclosure. International Journal of

[35] Freeman, R. E., Wicks, A. C., \& Parmar, B. (2004). Stakeholder theory corporate social responsibility. Journal of Business Ethics, 132(4),

[43] Harris, M. K. (2016). Professional Diversity of the Audit Committee and the Effect on the Financial Reporting Process. University of Nebraska,.

[44] Hassan, O., \& Marston, C. (2010). Disclosure measurement in the empirical accounting literature: A review article (Economics and Finance Working Paper Series No. No. 10-18). https://doi.org/http://dx.doi.org/10.2139/ssrn.1640598

[45] Hassan, R., Marimuth, M., Tariq, E., \& Aqeel, R. (2017). Ethnic and gender diversity in top level management and firm performance: Shareholder's perspectives. Journal of International Women's Studies, 18(4), 1-12. Retrieved from http://vc.bridgew.edu/jiws/vol18/iss4/1\%0A

[46] Hayes, A. F. (2013). Introduction to mediation, moderation and conditional process analysis: A regression based approach. Retrieved from www.guilford.com/p/hayes3

[47] Healy, P. M., \& Palepu, K. G. (2001). Information asymmetry, corporate disclosure, and the capital markets: a review of the empirical disclosure literature. Journal of Accounting and Economics, 31(1), 405-440.

[48] Hili, W., \& Affes, P. H. (2012). Corporate boards gender diversity and earnings Persistence: The case of French listed firms. Global Journal of Management and Business Resaerch, 12(22), 2249-4588.

[49] Ho, S. S. M., \& Wong, K. S. (2001). A study of the relationship between corporate governance structures and the extent of voluntary disclosure. Journal of International Accounting, Auditing and Taxation, 10(2), 139-156. https://doi.org/10.1016/S1061-9518(01)00041-6

[50] Hongxia, L., \& Ainian, Q. (2008). Impact of corporate governance on voluntary disclosure in Chinese listed companies. Corporate Ownership and Control, 5(2).

[51] Inchausti, B. na G. (1997). The influence of company characteristics and accounting regulation on information disclosed by Spanish firms. European Accounting Review, 6(1), 45-68. https://doi.org/10.1080/096381897336863

[52] Jensen, M., \& Meckling, W. (1976). Theory of the firm: Managerial behaviour, agency costs and ownership structure. Journal of Financial Economics, 3, 305-360.

[53] Juhmani, O. I. (2013). ownership structure and corporate voluntary visclosure: Evidence from Bahrain. International Journal of Accounting and Financial Reporting, 3(2), 133. https://doi.org/10.5296/ijafr.v3i2.4088

[54] Kamonjoh, E. (2014). Gender diversity on boards: A Review of Global Trends. ISS Governance.

[55] Katmon, N., Mohamad, Z. Z., Norwani, N. M., \& Al-Farooque, O. (2017). Comprehensive board diversity and quality of corporate socia responsibility disclosure: Evidence from an emerging market. Journal of Business Ethics, 1-35. https://doi.org/10.1007/s10551-017-3672-6

[56] Klein, A. (2002). Economic determinants of audit committee independence. The Accounting Review, 77(2), 435-52.

[57] Lambert, R. A. (2001). Contracting theory and accounting. Journal of Accounting and Economics, 32(1), 3-87.

[58] Leuz, C., Triantis, A., \& Yue Wang, T. (2008). Why do firms go dark? Causes and economic consequences of voluntary SEC deregistrations. Journal of Accounting and Economics, 45(2-3), 181-208. https://doi.org/10.1016/j.jacceco.2008.01.001

[59] Li, J., Mangena, M., \& Pike, R. (2012). The effect of audit committee characteristics on intellectual capital disclosure. The British Accounting Review, 44(2), 98-110. https://doi.org/10.1016/j.bar.2012.03.003

[60] Li, J., Mangena, M., \& Pike, R. (2012). The effect of audit committee characteristics on intellectual capital disclosure. The British Accounting Review, 44(2), 98-110.

[61] Liao, L., Luo, L., \& Tang, Q. (2015). Gender diversity, board independence, environmental committee and greenhouse gas disclosure. British Accounting Review, 47(4), 409-424. https://doi.org/10.1016/j.bar.2014.01.002

[62] MacKinnon, D., Fairchild, A., \& Fritz, M. (2007). Mediation analysis. Annual Review of Psychology, 58, 593-602. https://doi.org/10.1146/annurev.psych.58.110405.085542.Mediation

[63] Madi, H. K., Ishak, Z., \& Manaf, N. A. A. (2014). The impact of audit committee characteristics on corporate voluntary disclosure. Procedia Social and Behavioral Sciences, 164, 486-492. https://doi.org/10.1016/j.sbspro.2014.11.106

[64] Martinov-Bennie, N., Soh, D. S. B., \& Tweedie, D. (2015). An investigation into the roles, characteristics, expectations and evaluation practices of audit committees. Managerial Auditing Journal, 30(8/9), 727-755. https://doi.org/10.1108/MAJ-05-2015-1186

[65] McKinnon, J., \& Dalimunthe, L. (2009). Voluntary disclosure of segment information by Australian diversified companies. Accounting and Finance Research, 33(1), 33-50).

[66] McMullen, D. A. (1996). Audit committee performance: An investigation of the consequences 


\section{Audit Committee Diversity toward Voluntary Disclosure Reporting With Existence of Regulatory Regime as Moderation Variable}

associated with audit committees. Auditing: A Journal of Practice and Theory, 15(1), 87-103.

[67] McNulty, T., Zattoni, A., \& Douglas, T. (2013). Developing corporate governance research through qualitative methods: A Review of previous studies. Corporate Governance: An International Review, 21(2), 183-198. https://doi.org/10.1111/corg.12006

[68] Meek, G. K., Roberts, C. B., \& Gray, S. J. (1995). Factors influencing voluntary report disclosures by U.S., U.K. and Continental European multinational corporations. Journal of International Business Studies, 26(3), 555-572.

[69] Mohd-Nasir, N., \& Abdulah, S. N. (2004). Voluntary disclosure and corporate governance among financially distressed listed firms in Malaysia. Financial Reporting, Regulation and Governance, 1(1), 95-139.

[70] Morris, R. (1987). Signalling, agency theory and accounting policy choice. Accounting and Business Research, 18(69), 47-56.

[71] Othman, R., Farhana, I., Maznah, S., Arif, M., \& Abdul, N. (2014). Influence of audit committee characteristics on voluntary ethics disclosure. Procedia - Social and Behavioral Sciences, 145, 330-342. https://doi.org/10.1016/j.sbspro.2014.06.042

[72] Pige, B. (2002). Stakeholder theory and corporate governance: The nature of the board information. Management Journal of Contemporary Issue, 7(1), 1-17.

[73] Rao, K., \& Tilt, C. (2016). Board composition and corporate social responsibility: The role of diversity, gender, strategy and decision making. Journal of Business Ethics, 138(2), 327-347. https://doi.org/10.1007/s10551-015-2613-5

[74] Razek, M. A. (2015). The association between corporate social responsibility disclosure and corporate governance ... Research Journal of Finance and Accounting, 5(1), 2222-2847. Retrieved from www.iiste.org

[75] Rouf, M. A. (2016). Board diversity and corporate voluntary disclosure in the annual reports of Bangladesh. Risk Governance and Control: Financial Markets and Institutions, 6(4), 48-55.

[76] Samaha, K., Khlif, H., \& Hussainey, K. (2015). The impact of board and audit committee characteristics on voluntary disclosure: A meta-analysis. Journal of International Accounting, Auditing and Taxation, 24, 13-28. https://doi.org/10.1016/j.intaccaudtax.2014.11.001

[77] Shehata, N. F. (2014). Theories and Determinants of Voluntary Disclosure. Accounting and Finance Research, 3(1), 18-26. https://doi.org/10.5430/afr.v3n1p18

[78] Solomon, J. (2010). Corporate Governance and Accountability (Third ed.). United Kingdom: John Wiley \& Sons, Inc.

[79] Song, J., \& Windram, B. (2004). Benchmarking audit committee effectiveness in financial reporting. International Journal of Auditing, 8(3), 195-205. https://doi.org/10.1111/j.1099-1123.2004.00090.x

[80] Sukthomya, D. (2011). The empirical evidence of voluntary disclosure in the annual reports of of listed companies: The case of Thailand. University of Nottingham. Retrieved from http://eprints.nottingham.ac.uk/12903/1/555604.pdf

[81] Uzun, H., Szewczyk, S. H., \& Varma, R. (2004). Board composition and corporate and corporate fraud. Financial Analysts Journal, 33-43.

[82] Wagana, D. M., \& Nzulwa, J. D. (2016). Corporate governance, board gender diversity and corporate performance: A critical review $\mathrm{cf}$ literature. European Scientific Journal, 12(7), 221-234. https://doi.org/10.19044/esj.2016.v12n7p221

[83] Walker, R. G. (2004). Gaps in guidelines on audit committees. Abacus, 40(2), 157-192.

[84] Wang, M., \& Hussainey, K. (2013). Voluntary forward-looking statements driven by corporate governance and their value relevance. Journal of Accounting and Public Policy, 32(3), 26-49. https://doi.org/10.1016/j.jaccpubpol.2013.02.009

[85] Wu, H., Patel, C., \& Perera, H. (2015). Implementation of audit committee and independent director for financial reporting in China. Advances in Accounting, 31(2), 247-262. https://doi.org/10.1016/j.adiac.2015.09.005

[86] Xie, B., Davidson, W. N., \& Dadalt, P. J. (2003). Earnings management and corporate governance: The role of the board and the audit committee. Journal of Corporate Finance, 9(3), 295-316. https://doi.org/10.1016/S0929-1199(02)00006-8

[87] Yasin, F., Muhamad, R., \& Sulaiman, N. (2014). Corporate Governance Research: A Review of Qualitative Literature. International Conference on Technology and Business Management, 14-25. Retrieved from http://www.icmis.net/14TProceedings/pdf/D4145-final.pdf

\section{Authors ProfiLe}

My name is Ali Shariff Kabara, belong to Department of Accounting and Finance, Faculty of Management,Universiti Teknologi Malaysia, Johor, Malaysia, for more details contact me at alishariff080@gmail.com

My name is Dewi Fariha Abdullah, woring with Department of Accounting and Finance, Faculty of Management, Universiti Teknologi Malaysia, Johor, Malaysia

I am Aniza Bint Othman, affiliated with Department of Accounting and Finance, Faculty of Management, Universiti Teknologi Malaysia, Johor, Malaysia 